\title{
PEDIATRIC NURSES' KNOWLEDGE AND SKILLS IN EVIDENCE- BASED TECHNIQUE OF SECRETION SUCTIONING FROM A TRACHEOSTOMY TUBE
}

\author{
Silva Kostyliovienè $\dot{1}^{1,4}$, Alina Vaškelytė ${ }^{1,2}$, Dovilè Grinkevičiūte் $\dot{e}^{3,4}$ \\ ${ }^{1}$ Kaunas Collegium Nursing Department, ${ }^{2}$ Lithuanian University of Health Sciences Nursing and \\ Care Department, ${ }^{3}$ Lithuanian University of Health Sciences Pediatric Department, \\ ${ }^{4}$ Lithuanian University of Health Sciences Hospital Pediatric Intensive care Unit
}

Key words: evidence-based practice; pediatric nurses' knowledge; pediatric nurses' skills; secretion suctioning from a tracheostomy tube; tracheostomy care.

\begin{abstract}
Summary
In order to ensure the quality of tracheostomy care, nurses should have good knowledge and practical skills based on evidence-based practice. This study aims to analyse pediatric nurses' knowledge and skills in evidence-based technique of secretion suctioning from tracheostomy tube. The study was conducted in the Pediatric Intensive Care Unit and three pediatric units. Questionnaire and Protocol for observation of practical skills were created. Sixty-nine nurses were questioned and thirty-two procedures of secretion suctioning from a tracheostomy tube observed.

Nearly a fifth of the respondents $(23.2 \%)$ indicated that it was usual to perform the secretion suctioning from a tracheostomy tube every few hours, during observations nurses performed secretion suctioning if at least one of the clinical criteria for the need of secretion suctioning was met. In practice, the pressure during procedure was set at $50-120 \mathrm{mmHg}$ in the majority of procedures $(95.5 \%)$, even though more than a half of the respondents $(53.6 \%)$ indicated they performed secretion suctioning using the pressure higher than $150 \mathrm{mmHg}$ or the highest pressure available in the pump.

In practice, pediatric nurses providing tracheostomy care correctly applied their knowledge on the need for secretion suctioning from a tracheostomy tube. About a third of pediatric nurses did not follow the recommended steps of secretion suctioning procedure; in some cases the recommended suctioning pressure was not applied.
\end{abstract}

In order to ensure patient's safety and qualified tracheostomy care we have to rely on evidence-based nursing. Nurses not always know and use evidence - based tracheostomy care recommendations. This study revealed problematic aspects in tracheostomy care and proved that standardized tracheostomy care protocols have to be implemented, tracheostomy care study program for nurses based on evidence-based practice must be prepared, and tracheostomy teams in the hospitals have to be established.

\section{Introduction}

Tracheostomy is performed on patients in order to maintain a patent airway and if prolonged mechanical ventilation is necessary [1]. Most frequently, tracheostomy is performed when patients are in need of prolonged artificial lung ventilation, in order to keep the airway open or avoid aspiration in case of patients with traumatic brain injuries or neurological damage $[2,3]$. Patients with tracheostomy tubes can be in all nursing units, not only in critical care departments [4]. When nursing such patients, nurses are expected to have adequate knowledge and skills in order to ensure safe and effective healthcare services [5, 6]. Paul F. (2010) maintains that nonICU nurses may experience anxiety or stress when they have to take care of patients with tracheostomy transferred from the ICU [6]. Patient outcomes improvement and health costs reduction can be achieved by informed, educated, skilled nurses, using evidence-based practice [7].

Nurses have to perform vacuum based secretion suctioning from a tracheostomy tube for patients with tracheostomy tubes. This procedure is an effective method to ensure patency of the airway $[3,8,9]$. Even the small amounts of accumulated secretions can affect respiratory function of children. Secretion suctioning from a tracheostomy tube is a high-risk procedure [5], even more risk is for severely ill 
children [10]. However, there is insufficient scientific evidence-based advice to children on the secretion suctioning from a tracheostomy tube $[7,10]$, many aspects of secretion suctioning are based on the recommendations of adult patient secretion suctioning. Tracheostomy care management and techniques of secretion suctioning from a tracheostomy tube are associated with complications $[5,11]$, and may contribute to patient safety, recovery prospects, treatment duration and costs [11]. Research done in Denmark [12], Holland [13] reported the lack of guidelines for nursing of patients with tracheostomy tubes transferred from the ICU to other units. In order to ensure and improve the quality of tracheostomy care services, nurses should have good knowledge and practical skills based on current research [14, 15]. Nurses are expected to be competent enough to decide if there is a clinical need for secretion suctioning from a tracheostomy tube [7].

Studies conducted in other countries demonstrate that in providing tracheostomy care for adult patients nurses are not always following evidence based practice [16-20]. Day et al (2009) maintain that it is not sufficient simply to evaluate nurses' theoretical knowledge as it may poorly reflect practical skills [19]. For this reason, this study was designed to explore nurses' knowledge on tracheostomy care for chil-

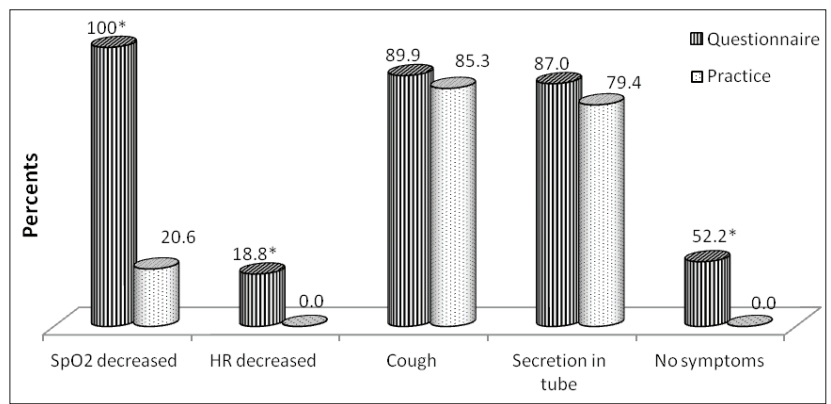

Figure 1. Indications for the need of secretion suctioning from a tracheostomy tube

$* p<0.05$ comparing with practice

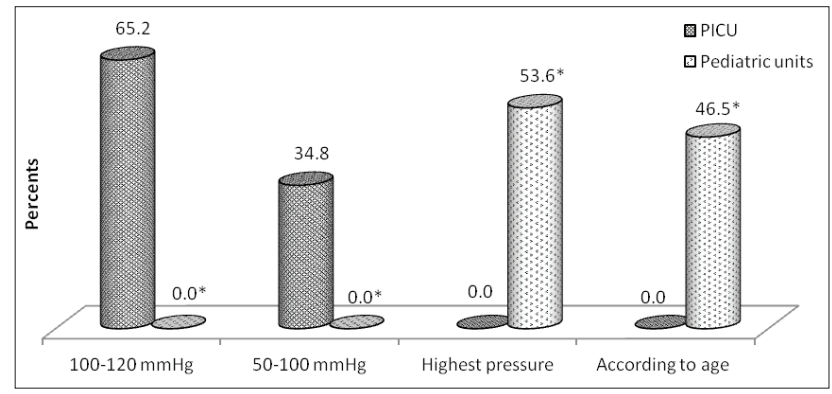

Figure 2. Pressure of secretion suctioning from a tracheostomy tube $* p<0.05$ comparing with PICU dren and to find out whether nurses applied this knowledge in clinical practice.

This study aims to analyse pediatric nurses' knowledge and skills in evidence-based technique of secretion suctioning from a tracheostomy tube.

\section{Methods}

The study was conducted in 2013 at the University Hospital PICU and three pediatric units receiving patients with tracheostomy from the PICU. All 71 nurses working at these units were invited to take part in the study. The study was carried out in the following stages: A questionnaire survey of nurses; Training for nurses; a non-participant structured observation of practical nurses' skills during secretion suctioning from a tracheostomy tube.

After completing the anonymous questionnaire survey the following training took place: a lecture that lasted for two academic hours and a seminar - "Evidence-based tracheostomy care". Afterwards active discussions with nurses were held.

Seventy one questionnaires were distributed to nurses who agreed to take part in the questionnaire survey, 69 qu-

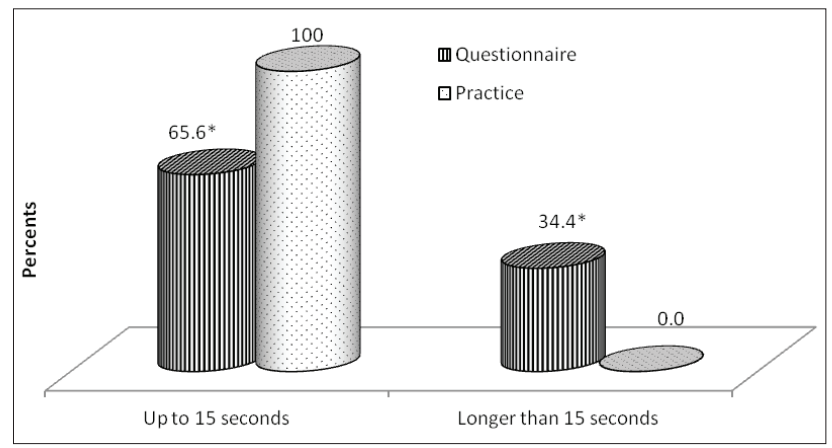

Figure 3. Duration of secretion suctioning from a tracheostomy tube $* p<0.05$ comparing with practice

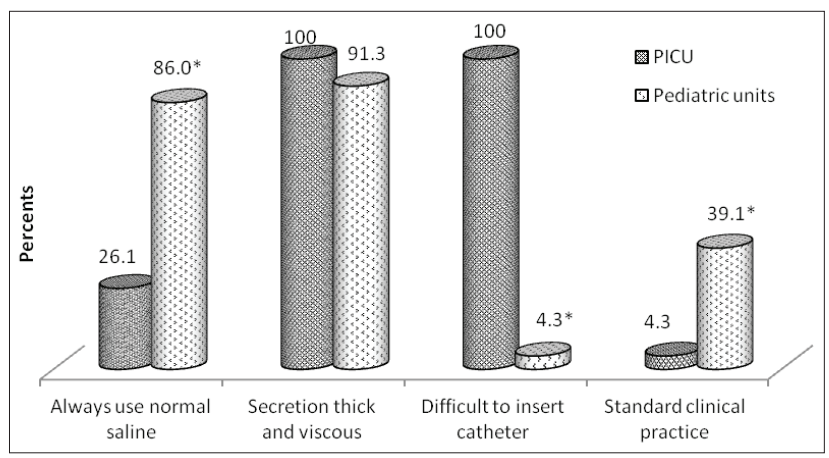

Figure 4. The use of normal saline during secretion suctioning from a tracheostomy tube $* p<0.05$ comparing with PICU 
estionnaires were returned and used for data analysis, and the response rate was $97.2 \%$. Thirty-two procedures of secretion suctioning from a tracheostomy tube were observed, observation lasted for 32 hours.

Respondent age distribution was as follows: $4.4 \%$ of respondents were younger than $29,13 \%$ of respondents were in the age group from 30 to $39,53.6 \%$ of respondents were aged from 40 to 49 and $29.0 \%$ of respondents were older than 50 .

The majority of respondents $(76.8 \%)$ were graduates of medical schools, a tenth of all respondents $(10.2 \%)$ had nonuniversity higher education and about a sixth of respondents $(13.0 \%)$ were university graduates.

The majority of respondents $(91.3 \%)$ had more than 10 years, $5.8 \%$ - from 6 to 10 years, and $2.9 \%$ - less than 5 years of clinical experience.

The study was conducted based on a Nurses' knowledge assessment survey consisting of 31 questions prepared by authors. Practical steps taken by nurses during secretion suctioning from a tracheostomy tube were registered in the Protocol for observation of practical nurses' skills developed by authors. The protocol and the survey were prepared according evidence-based technique requirements.

For an analysis of results and presentation of survey data the following numerical characteristics of descriptive statistics were used: the mean, the standard deviation, the frequency distribution expressed as percentages. If the distribution between the samples did not satisfy the assumption of normality, the Mann-Whitney rank test was used to compare two samples, and the Kruskal-Wallis test was applied, if there were more than two samples. In case of a normal distribution between two samples, the t-test or the Student's test was applied, and if there were more than two samples, ANOVA test was used. A statistical correlation of qualitative variables was analysed by applying the method of contingency tables. Based on data of contingency tables, the value of the $\chi^{2}$ (chi-square), the degrees of freedom (df) and statistical significance were calculated as follows: if $p>0.05$ - the difference was not statistically significant, if $p<0.05$ - the difference was statistically significant, if $p<0.01$ - the difference was very significant.

Ethical approval to conduct the study was obtained from the LSMU Bioethics Committee.

\section{Results}

In the questionnaire survey the majority of pediatric nurses $(72.2 \%)$ indicated that they would start secretion suctioning from the child's mouth and nose, however, in practice this order (the mouth, nose, tracheostomy tube) was registered only in about half $(53.3 \%)$ of observed cases $\left(\chi^{2}=3,401\right.$; $\mathrm{df}=1 ; \mathrm{p}=0,005)$.
This study aimed to explore what symptoms pediatric nurses took into consideration to assess the patient's need for secretion suctioning from a tracheostomy tube. All nurses $(100 \%)$ indicated they suctioned secretion if the patient's $\mathrm{SpO}_{2}$ decreased and about a fifth of respondents (18.8\%) considered the decreased heart rate (HR) as an indication for secretion suctioning. The majority of respondents stated they suctioned secretion if the patient had a cough $(89.9 \%)$, if there were visible secretion in a tracheostomy tube (87.0\%).

During observation of practical nurses' actions, it was found that before secretion suctioning from a tracheostomy tube secretion were visible in a tracheostomy tube (79.4\%), the majority of patients $(85.3 \%)$ had a cough, the decrease in $\mathrm{SpO}_{2}$ was present only in a fifth of patients $(20.6 \%)$. No decrease in the HR was observed.

Although nearly a fifth of the questionnaire survey respondents $(52.2 \%)$ - indicated that it was usual to perform the procedure every few hours even in the absence of any symptoms, in practice, however, pediatric nurses performed secretion suctioning if at least one of the clinical criteria for the need of secretion suctioning procedure was met (Fig. 1).

The decrease in $\mathrm{SpO}_{2}$ was significantly more frequently observed in pediatric units (41.7\%) than in the PICU (9.1\%) $\left(\chi^{2}=5.040 ; \mathrm{df}=1 ; \mathrm{p}=0.025\right)$, while coughing was observed in nearly all cases $(95.5 \%)$ at the PICU and in more than a half of procedures $(66.7 \%)$ observed in pediatric units $\left(\chi^{2}=5.130\right.$; $\mathrm{df}=1 ; \mathrm{p}=0.024)$. Visible secretion in the tracheostomy tube were observed for all patients $(100 \%)$ in pediatric units, while this symptom occurred significantly less frequently in the PICU $(68.2 \%)\left(\chi^{2}=4.808 ; \mathrm{df}=1 ; \mathrm{p}=0.028\right)$.

Data of the questionnaire survey revealed a statistically significant difference between groups $\left(\chi^{2}=66.000 ; \mathrm{df}=3\right.$; $\mathrm{p}<0.001)$ in the selection of suction pressure for secretion suctioning from a tracheostomy tube: more than a half of nurses working at the PICU (65.2\%) said they used the pressure of $100-120 \mathrm{mmHg}$, about a third (34.8\%) of nurses used the pressure of $50-100 \mathrm{mmHg}$, while about a half of nurses $(53.6 \%)$ working in pediatric units indicated they used the highest pressure available in the pump of or set the pressure according to the child's age (46.5\%).

During practical observation in the PICU, it was found that the average suction pressure was $107.7 \mathrm{mmHg}$, the lowest pressure $-100 \mathrm{mmHg}$, the highest pressure -120 $\mathrm{mmHg}$. In pediatric units the average suction pressure was 137.84 , the lowest pressure $-75 \mathrm{mmHg}$, the highest pressure $-301 \mathrm{mmHg}$. A statistically significant difference $\left(\chi^{2}=31.850 ; \mathrm{df}=1 ; \mathrm{p}<0.001\right)$ was found as a result of comparison between the pressure for secretion suctioning from a tracheostomy tube indicated by pediatric nurses in the questionnaire survey and the actual suction pressure used 
in practice. In clinical practice, the pressure during secretion suctioning from a tracheostomy tube was set at 50-120 $\mathrm{mmHg}$ in the majority of procedures $(95.5 \%)$, even though more than a half of the questionnaire survey respondents $(53.6 \%)$ indicated they performed secretion suctioning from a tracheostomy tube using the pressure higher than $120 \mathrm{mmHg}$ or the highest pressure available in the pump (Fig. 2).

The majority of respondents believed that the duration of secretion suctioning should be 5-15 seconds, however, compared to the PICU nurses (13.0\%) a significantly larger percentage of nurses working at pediatric units (45.7\%) indicated that they continued secretions suctioning until it was fully removed $\left(\chi^{2}=9.531 ; \mathrm{df}=2 ; \mathrm{p}=0.008\right)$.

During practical observation of nurses' actions in the PICU it was found that the average duration of suction was 8 seconds, the shortest duration -1 second, the longest duration -15 seconds. In pediatric units the average duration of secretion suctioning was 10 seconds, the shortest duration -7 seconds, the longest duration -15 seconds. In all observed suctioning procedures $(100 \%)$ the duration of suction was up to 15 seconds, although a third of the questionnaire survey respondents (34.4\%) stated that secretion suctioning from a tracheostomy tube took longer than 15 seconds or until secretions were fully removed $\left(\chi^{2}=15.419 ; \mathrm{df}=1 ; \mathrm{p}<0.001\right)$ (Fig. 3).

Results of the questionnaire survey revealed that compared to nurses working in pediatric units $(86.0 \%)$ a significantly smaller percentage of the PICU nurses $(26.1 \%)$ indicated they always added use normal saline instillation into a tracheostomy tube during the secretion suctioning procedure $(\chi 2=23.492 ; \mathrm{df}=2 ; \mathrm{p}<0.0001)$. All PICU nurses $(100 \%)$ and the majority of nurses working in pediatric units (91.3\%) indicated that they use normal saline instillation, if secretion in the tracheostomy tube were thick and viscous, and only a small percentage of nurses working in pediatric units $(4.3 \%)$ use normal saline if it was difficult to insert a suction catheter into a tracheostomy tube and the suction catheter got stuck to the tracheostomy tube walls $\left(\chi^{2}=60.720 ; \mathrm{df}=1 ; \mathrm{p}<0.0001\right)$. Only one PICU nurse (4.3\%) and more than a third of nurses working in pediatric units (39.1\%) maintained that it was a standard clinical practice to use normal saline instillation into a tracheostomy tube during the secretion suctioning procedure $\left(\chi^{2}=9.297 ; \mathrm{df}=1 ; \mathrm{p}<0.002\right)$ (Fig. 4).

Compared to nurses working in pediatric units (37.0), a significantly larger percentage of the PICU nurses (65.2\%) indicated that the amount of used normal saline (in milliliters) depended on the child's age $\left(\chi^{2}=8.808 ; \mathrm{df}=3 ; \mathrm{p}<0.032\right)$. During the observed secretions suctioning procedures normal saline was not used at all in the PICU $(0 \%)$ as well as in most cases in pediatric units $(75 \%)\left(\chi^{2}=6.032 ; \mathrm{df}=1 ; \mathrm{p}<0.014\right)$.
Although more than a half of the questionnaire survey respondents $(62.3 \%)$ pointed out they would use normal saline during the secretion suctioning procedure, in practice this was done only by a very small percentage of pediatric nurses $(8.8 \%)\left(\chi^{2}=26.373 ; \mathrm{df}=1 ; \mathrm{p}<0.0001\right)$.

\section{Discussion}

This study was designed to explore pediatric nurses' knowledge in evidence based technique of secretion suctioning from a tracheostomy tube, whether it complied with evidence based recommendations, and how this procedure was performed in clinical practice.

The majority recommendations are for endotracheal suctioning, we did not find any recommendations for suctioning from tracheostomy tube in children.

Results of our observational study on practical pediatric nurses' skills are very similar to findings of other researchers, who revealed that nurses' knowledge was not always in line with the current research recommendations and differed from clinical practice $[16-18,20]$.

Endotracheal suctioning is associated with several potential complications such as bradycardia, arrhythmia, hypoxia, tracheal wall damage, infection and others complications [21], therefore, it is recommended to perform secretion suctioning only when it is necessary $[8,9,14,15]$. In recommendations suggested by Tume and Copnell (2015) pediatric intensive care nurses should thoroughly evaluate and determine need of tracheal suctioning and take precautionary measures in order to minimize the risk of procedure [10].

The findings of an observational study by Kelleher, Andrews (2008) suggest that prior to endotracheal suctioning nurses failed to auscultate the patient's chest and frequently performed secretion suctioning based on only one symptom for the need of suctioning [20].

Our study findings demonstrated that in the questionnaire survey nurses pointed out that they routinely performed secretion suctioning every few hours, however, observation results revealed that in practice nurses performed secretion suctioning even if one clinical symptom for the need of secretion suctioning procedure was present. In Lithuania it is still unusual for nurses to auscultate the patient's chest in order to verify the need for secretion suctioning from a tracheostomy tube. Scientific researches proved that tracheostomy teams and a tracheostomy hospital service were associated with standardized protocols and provide better tracheostomy care [2]. In our country there is no uniform tracheostomy care standard. Each medical institution has its own adopted and approved procedures or work instructions. Consequently, nurses perform secretion suctioning from a tracheostomy tube in accordance to working instructions 
approved by a specific institution or its prevalent practice, which is not necessarily in compliance with evidence based recommendations. Research suggests that approved tracheostomy care standards or secretion suctioning protocols may assist in the nurses' training process or guide inexperienced nurses in clinical practice [7].

Though there is lack of clear recommendations about suctioning pressure for children, Ireton, Joanna (2007) recommends setting suctioning pressure at the lower limits according to child's age: $80-120 \mathrm{mmHg}(10-16 \mathrm{Kpa})$ for adolescents, $80-10 \mathrm{OmmHg}(10-13 \mathrm{Kpa})$ for children and $60-80 \mathrm{mmHg}(8-10 \mathrm{Kpa})$ for neonates [8]. In some situations there is potential for high negative pressures to be generated and staff should be aware of that [10]. A study conducted in Finland (2012) revealed that only in case of slightly more than a tenth $(15 \%)$ of procedures observed in the ICU the used suction pressure was $80-150 \mathrm{mmHg}$ [19]. According to results of the study carried out in Ireland (2008), suction pressures exceeded the recommended levels and ranged from 230 to $450 \mathrm{mmHg}$ [20]. The results of the survey conducted 2013 in Lithuania showed, that more than half of the nurses (60.1\%) would do the suctioning from tracheostomy tube at the pressure that is set in the suction machine and more than a tenth $(11.9 \%)$ - at the maximum pressure available in suction machine. Observations in departments were tracheostomized patients are moved from intensive care showed that in majority of the cases $(86.9 \%)$ pressure greater than $150 \mathrm{mmHg}$ was used [22].

Results of our study demonstrate that too high pressure was rarely used for secretion suctioning from a tracheostomy tube performed on children: during practical observation the average suction pressure was $107.7 \mathrm{mmHg}$ for procedures in the PICU and $137.84 \mathrm{mmHg}$ for procedures in pediatric units. The highest pressure of $301 \mathrm{mmHg}$ was observed only in pediatric units during very few secretion suctioning episodes. Since secretion suctioning pressure is adjusted in accordance to the child's age $[8,9,14,15]$, it may be presumed that when a new patient is admitted to the unit nurses set the suction pressure required for a particular patient. However, even rare cases of using higher than recommended suction pressure are a cause for concern because the use of excessive suction pressure increases the risk of lung injury or the flow of secretions accumulated above the tube cuff into the trachea [23].

The recommended suctioning time is up to $5-15 \sec [9$, $10,14,15]$. In Lithuanian study (2013) nurses from ordinary adult and children department were surveyed. Almost half or respondents $(46.7 \%)$ stated that one-time catheter insertion and suction should be up to $15 \mathrm{sec}$. During observation also almost in half of the cases $(45.5 \%)$ one time catheter insertion and suction lasted up to $15 \mathrm{sec}$ [22]. The study that took place in an adult ICU in England (2002) demonstrated that only a small percentage of nurses performed suctioning during 6-9 seconds [17]. In our study, as well as in the study conducted in Ireland (2008), there were no nurses that performed suctioning for longer than 15 seconds [20].

It is proven, that suctioning from subglottic space lowers the risk of ventilator - associated pneumonia [24]. In order to avoid secretion aspiration to lower respiratory tract routine oropharyngeal suctioning is recommended prior to suctioning from tracheostomy tube [25]. In this study, the majority of nurses indicated they performed secretion suctioning in reversed order: first, secretions are suctioned from a tracheostomy tube, then from the mouth and nose, however, during practical observation these steps were followed only in about a third of secretion suctioning procedures. This is of concern as secretion suctioning performed in this order increases the risk of infection [26].

Routine use of normal saline instillation into a tracheostomy tube during the secretion suctioning procedure is not recommended $[8,10,14,15]$. This factor may increase the number of complications. In Lithuanian study (2013) most of the nurses $(94.9 \%)$ from ordinary adult and children departments in the survey stated that they use sterile isotonic solution to tracheostomy tube for suctioning, but observation showed that it was done in significantly less cases $(9.3$ $\%$ comparing with the survey $\chi^{2}=138,857 ; 11 \mathrm{~s}=1 ; \mathrm{p}<0,001$ ) [22]. In our study, no nurses were observed to actually use normal saline in practice. Findings of this study revealed problem areas of tracheostomy care for children as a small percentage of pediatric nurses still selected the excessive suction pressure and performed suctioning longer than recommended as well as did not follow the correct order of procedural steps. Therefore, it may be presumed that changes in tracheostomy care management are necessary in order to ensure the patient safety and quality of care. Since there is no approved uniform tracheostomy care standard in Lithuania, pediatric nurses are free to perform the secretion suctioning procedure in a way customary at their workplace and not as recommended by evidence based nursing.

Our study results demonstrate that pediatric nurses' knowledge was not always applied in practice. We believe that it is advisable for nurses working in pediatric units to participate in training on tracheostomy care and that more attention should be paid to individual training of nurses at the workplace. Precise tracheostomy care guidelines are very important to those health care specialists who are infrequently involved in tracheostomy care. In clinical practice it is recommended to develop standard tracheostomy care guidelines and tracheostomy care charts containing all infor- 
mation on the patient and the formed tracheostomy necessary for nurses.

Study strengths and limitations. The main strengths of this study are related to the use of data source triangulation when data of the questionnaire survey and observation of practical nurses' skills were combined and compared.

The main limitations are that the study was confined to one hospital only. Observation of practical skills was direct; it might have created a possibility of the Hawthorne effect, when nurses made more effort to perform the procedure according to recommendations while in every day practice they conducted it differently, i.e. in the usual way.

\section{Conclusion}

1. In clinical practice, pediatric nurses providing tracheostomy care correctly applied their knowledge on the need for secretion suctioning from a tracheostomy tube, the use of normal saline, the duration of suctioning.

2. About a third of pediatric nurses did not follow the recommended steps of secretion suctioning procedure; also in some cases the recommended suctioning pressure was not applied.

\section{References}

1. De Leyn P, Bedert L, Delcroix M, Depuydt P, Lauwers G, Sokolov Y, Van Schil P. Tracheotomy: clinical review and guidelines. European Journal of Cardio-Thoracic Surgery 2007; 32(3): 412-421.

https://doi.org/10.1016/j.ejcts.2007.05.018

2. Cheung NH, Napolitano LM. Tracheostomy: epidemiology, indications, timing, technique, and outcomes discussion. Respiratory care $2014 ; 59(6)$ : 895-919. 10.4187/respcare.02971 https://doi.org/10.4187/respcare.02971

3. Morris LL, Whitmer A, McIntosh E. Tracheostomy care and complications in the intensive care unit. Critical Care Nurse 2013; 33(5): 18-30. https://doi.org/10.4037/ccn2013518

4. Regan EN, Dallachiesa L. How to care for a patient with tracheostomy. Nursing 2009; 39(8):34-39.

https://doi.org/10.1097/01.NURSE.0000358572.79112.bd

5. Nance-Floyd B. Tracheostomy care: an evidence based guide to suctioning and dressing changes. Am Nurs Today 2011; 6(7): 14-16. Retrieved from: https://www.americannursetoday.com/ tracheostomy-care-an-evidence-based-guide-to-suctioningand-dressing-changes/

6. Paul F. Tracheostomy care and management in general wards and community settings: literature review. Nursing in Critical Care 2010; 15(2):76-85.

7. Davies K, Monterosso L, Bulsara M, Ramelet AS. Clinical indicators for the initiation of endotracheal suction in children: An integrative review. Australian Critical Care 2015; 28(1):11-18. https://doi.org/10.1016/j.aucc.2014.03.001

8. Freeman S. Care of adult patients with a temporary tracheostomy. Nursing Standard 2011; 26(2): 49-56.

https://doi.org/10.7748/ns.26.2.49.s52

9. Ireton J. Tracheostomy suction: a protocol for practice. Paediatric Nursing 2007; 19(10): 14-19. Retrieved from: https:// www.ncbi.nlm.nih.gov/pubmed/18196852

10. Tume LN, Copnell B. Endotracheal suctioning of the critically ill child. Journal of Pediatric Intensive Care 2015; 4(02): 056063.

11. Wood CJ. (1998). Can nurses safely assess the need for endotracheal suction in short term ventilated patients, instead of using routine techniques? Intensive and Critical Care Nursing 1998; 14(4): 170-178.

12. Mondrup F, Skjelsage K, Madsen KR. Inadequate follow up after tracheostomy and intensive care. Dan Med J 2012; 59(8): A4481.

13. Veelo DP, Schultz MJ, Phoa KY, Dongelmans DA, Binnekaded JM, Spronk PE. Management of tracheostomy: a survey of Dutch intensive care units. Respiratory Care 2008; 53(12): 1709-1715. Retrieved from: http://www.rcjournal.com/ contents/12.08/12.08.1709.pdf

14. American Association for Respiratory Care. Endotracheal suctioning of mechanically ventilated patients with artificial airways 2010. Respiratory Care 2010; 55(6):758-764.

15. Bodenham A, Bell D, Bonner S, Branch F, Dawson D, Morgan P. et al. Standards for the care of adult patients with temporary tracheostomy; standards and guidelines. Intensive Care Society Standards 2014. Retrieved from: https://www.theawsomecourse.co.uk/ICS/ICS\%20Tracheostomy\%20standards\%20(2014). pdf

16. Ansari A, Masoudi Alavi N, Adib-Hajbagheri M, Afazel, M. The gap between knowledge and practice in standard endotracheal suctioning of ICU nurses, Shahid Beheshti Hospital. Journal of Critical Care Nursing 2012; 5(2): 71-76. Retrieved from: http://inhc.ir/article-1-431-fa.pdf

17. Day T, Farnell S, Haynes S, Wainwright S, Wilson-Barnett J. Tracheal suctioning: an exploration of nurses' knowledge and competence in acute and high dependency ward areas. Journal of Advanced Nursing 2002; 39(1):35-45. https://doi.org/10.1046/j.1365-2648.2002.02240.x

18. Day T, Iles N, Griffiths P. Effect of performance feedback on tracheal suctioning knowledge and skills: randomized controlled trial. Journal of Advanced Nursing 2009; 65(7):1423-1431. https://doi.org/10.1111/j.1365-2648.2009.04997.x

19. Jansson M, Ala-Kokko T, Ylipalosaari P, Kyngäs H. Evaluation of endotracheal suctioning practices of critical care nurses an observational correlation study. Journal of Nursing Education and Practice 2013; 3(7): 99. https://doi.org/10.5430/jnep.v3n7p99

20. Kelleher S, Andrews T. An observational study on the open 
system endotracheal suctioning practices of critical care nurses. Journal of Clinical Nursing 2008; 17(3), 360-369. https://doi.org/10.1111/j.1365-2702.2007.01990.x

21. Morrow BM, Argent, A. C. A comprehensive review of pediatric endotracheal suctioning: Effects, indications, and clinical practice. Pediatric Critical Care Medicine 2008; 9(5): 465-477.

22. Vaškelytė A, Kostyliovienė S, Grinkevičiūtė D. Slaugytojų žinios ir ịgūdžiai atliekant sekreto išsiurbimą iš tracheostomos vamzdelio. Sveikatos mokslai, 2016; 26 (6):207-212. https://doi.org/10.5200/sm-hs.2016.118

23. Dave MH, Frotzler A, Madjdpour C, Koepfer N, Weiss, M. Massive aspiration past the tracheal tube cuff caused by closed tracheal suction system. Journal of Intensive Care Medicine 2011; 26(5): 326-329. https://doi.org/10.1177/0885066610392516

24. Lacherade JC, De Jonghe B, Guezennec P, Debbat K, Hayon J, Monsel A, Bastuji-Garin S. Intermittent subglottic secretion drainage and ventilator associated pneumonia: a multicenter trial. American Journal of Respiratory and Critical Care Medicine 2010; 182(7): 910-917. https://doi.org/10.1164/rccm.200906-08380C

25. Sole ML, Penoyer DA, Bennett M, Bertrand J, Talbert S. Oropharyngeal secretion volume in intubated patients: the importance of oral suctioning. Am J Crit Care. 2011; 20(6):e141e145.

https://doi.org/10.4037/ajcc2011178

26. Lorente L, Blot S, Rello J. New issues and controversies in the prevention of ventilator associated pneumonia. American Journal of Respiratory and Critical Care Medicine 2010; 182(7): 870-876.

https://doi.org/10.1164/rccm.201001-0081CI

\section{VAIKU SLAUGYTOJU ŽINIOS IR IGŪDŽIAI ATLIEKANT SEKRETO IŠSIURBIMĄ IŠ TRACHEOSTOMOS VAMZDELIO REMIANTIS MOKSLO İRODYMAIS GRĮSTA PRAKTIKA \\ S.Kostyliovienė, A.Vaškelytė, D.Grinkevičiūtė}

Raktažodžiai: vaikų slaugytojų žinios, vaikų slaugytojų igūdžiai, sekreto išsiurbimas iš tracheostomos vamzdelio, tracheostomos priežiūra.
Santrauka

Slaugytojams, slaugant pacientą su tracheostomos vamzdeliu, tenka atlikti sekreto išsiurbimą iš tracheostomos vamzdelio vakuumo pagalba. Tracheostomos priežiūros veiksmai bei sekreto išsiurbimo iš tracheostomos vamzdelio technika turi reikšmès komplikacijų atsiradimui ir gali lemti paciento saugumą, pasveikimo galimybę, gydymo trukmę bei kainą. Siekiant užtikrinti ir gerinti tracheostomos priežiūros teikiamų paslaugų kokybę, slaugytojams būtinos geros žinios ir praktiniai ịgūdžiai, pagrịsti moksliniais tyrimais. Darbo tikslas yra išanalizuoti vaikų slaugytojų žinias ir igūdžius atliekant sekreto išsiurbimą iš tracheostomos vamzdelio.

Tyrimas vyko $2013 \mathrm{~m}$. vienoje iš Lietuvos universitetinių ligoninių Vaikų intensyviosios terapijos skyriuje ir trijuose vaikų ligų skyriuose. Remiantis moksline literatūra, šiam tyrimui buvo sukurtas klausimynas bei Slaugytojų praktinių veiksmų stebejjimo protokolas. Apklausti 69 slaugytojai, atsako dažnis - 97,18 proc. Buvo stebètos 32 sekreto išsiurbimo iš tracheostomos vamzdelio procedūros. Tyrimui vykdyti gautas Bioetikos centro pritarimas.

Anketinès apklausos metu apie penktadalis respondentų (23,2 proc.) nurodè, kad ịprasta procedūrą atlikti kas kelias valandas, tačiau praktikoje slaugytojai sekretą siurbė esant nors vienam sekreto išsiurbimo poreikio požymiui. Klinikinèje praktikoje daugumos $(95,5$ proc.) procedūrų metu slègis sekreto išsiurbimo iš tracheostomos vamzdelio metu buvo 50 - $120 \mathrm{mmHg}$, nors anketinès apklausos metu apie pusė $(53,6$ proc.) respondentų nurodè, jog siurbia sekretą iš tracheostomos vamzdelio didesniu nei $150 \mathrm{mmHg}$ ar didžiausiu slėgiu, esančiu siurblyje.

Klinikineje praktikoje atliekant tracheostomos priežiūrą vaikų slaugytojai tinkamai taikè turimas žinias apie sekreto iš tracheostomos vamzdelio išsiurbimo poreikị, sol. $\mathrm{NaCl} 0,9$ proc. tirpalo naudojimą, siurbimo trukmę. Apie trečdalis vaikų slaugytojų atliekant procedūrą netaikè rekomenduojamos sekreto siurbimo veiksmų sekos, atskirais atvejais netaikè rekomenduojamo siurbimo slègio.

Adresas susirašinèti: alina.vask@gmail.com

Gauta 2018-09-16 